Magdalena Szyszko*

\title{
KSZTAŁTOWANIE OCZEKIWAŃ INFLACYJNYCH PRZEZ PROGNOZY INFLACJI W ŚWIETLE BADAŃ EMPIRYCZNYCH ${ }^{1}$
}

\section{Wprowadzenie}

Nowoczesne banki centralne najczęściej wdrażają strategię bezpośredniego celu inflacyjnego (inflation targeting, BCI). Naukowcy akademiccy i praktycy - bankierzy centralni, zgodni są co do tego, że jest to najskuteczniejszy sposób realizacji celów makroekonomicznych - przede wszystkim celu inflacyjnego - wobec mechanizmów funkcjonowania współczesnych gospodarek. Strategia ta nakierowana jest na kształtowanie oczekiwań inflacyjnych podmiotów gospodarczych. Bank centralny wykorzystuje kilka sposobów wywierania wpływu na oczekiwania: od najprostszych, takich jak wykorzystywanie ogłoszonego numerycznie celu inflacyjnego jako kotwicy nominalnej, po bardziej wyrafinowane, takie jak prognoza inflacji, której sporządzenie jest wyzwaniem dla ekspertów banku centralnego. Niniejszy artykuł poświęcony jest właśnie zagadnieniom związanym z wpływem prognozy inflacji na oczekiwania inflacyjne konsumentów. Wywieranie tego wpływu jest podstawową rolą prognoz inflacji banku centralnego.

Badaniom, których wyniki zaprezentowano w tekście, przyświecała chęć weryfikacji hipotezy badawczej zakładającej istnienie współzależności między prognozami inflacji sporządzanymi przez bank centralny a oczekiwaniami inflacyjnymi konsumentów. Badania przeprowadzono na próbie dwóch krajów: Czech i Szwecji. Narodowy Bank Czech (NBC, Česká národí banka) i Bank Szwecji (SR, Sveriges Riksbank) wdrażają strategię celu inflacyjnego i przez relatywnie długi okres (co szczególnie istotne w wypadku młodej gospodarki rynkowej) sporządzają i publikują prognozy inflacji. Jednocześnie eksponują prognozy w komunikacji z rynkiem. Szwecja była

\footnotetext{
* Wyższa Szkoła Bankowa w Poznaniu, Wydział Finansów i Bankowości.

1 Badania stanowiące podstawę niniejszej publikacji zrealizowane zostały w ramach projektu finansowanego ze środków Narodowego Centrum Nauki przyznanych na podstawie decyzji numer DEC-2011/ 03/B/HS4/03705.
} 
jednym z prekursorów strategii BCI, dlatego jej doświadczenia w wykorzystaniu prognoz inflacji są dobrym tłem do porównań.

Badania przeprowadzono z wykorzystaniem kilku metod, których trzon stanowiły metody statystyczne: kwantyfikacja oczekiwań inflacyjnych oraz poszukiwanie istnienia współzależności między oczekiwaniami a prognozami.

Struktura artykułu dostosowana jest do realizacji celu, przy czym dwie pierwsze części mają charakter opisowy i stanowią skrócony przegląd dorobku teoretycznego. Odnoszą się one do oczekiwań inflacyjnych jako centralnego punktu polityki monetarnej oraz - część druga - do miejsca prognoz w nowoczesnej polityce monetarnej. Po części metodologicznej następuje prezentacja wyników badań empirycznych.

\section{Oczekiwania w polityce pieniężnej}

Współczesny mechanizm transmisji monetarnej, wpisany w ramy nowej syntezy neoklasycznej (NSN) opiera się w zasadzie na trzech równaniach opisanych w tabeli 1. Eksponują one znaczenie oczekiwań inflacyjnych dla możliwości bezpośredniego i pośredniego (przez lukę popytową i kanał zagregowanego popytu) wpływu na inflację. Inflacja ma charakter antycypacyjny, co wyprowadzone zostało $\mathrm{z}$ modelu niejednoczesnego dostosowywania się cen².

Rola oczekiwań inflacyjnych w polityce pieniężnej została wyeksponowana w ramach nowoczesnej strategii monetarnej. Koncentracja na celu inflacyjnym, uczynienie go kotwicą nominalną, podbudowa instytucjonalna czy uwolnienie banku centralnego od konieczności obrony kursu walutowego mają wzmacniać przełożenie działań władz monetarnych na oczekiwania inflacyjne. Bank centralny chce kształtować oczekiwania oraz bacznie je obserwować ze względu na to, że stanowią one podstawowy miernik jego wiarygodności. Koncentracja polityki pieniężnej na oczekiwaniach, zgodna $\mathrm{z}$ teorią ekonomii, znalazła również potwierdzenie w badaniach empirycznych - oczekiwania inflacyjne wywierają istotny i wielopłaszczyznowy wpływ na gospodarkę poprzez oddziaływanie m.in. na konsumpcję, stopę

2 Zgodnie z modelem Calvo, przedsiębiorstwa nie mogą zmieniać cen $\mathrm{w}$ dowolnym momencie, ale $\mathrm{w}$ wybranym losowo okresie. Prawdopodobieństwo dokonywania zmiany ceny w okresie $t$ jest niezależne od momentu ostatniej zmiany ceny. Nie zależy także od przedsiębiorstwa i jego związków z innymi. Przedsiębiorstwo zdaje sobie sprawę, że może nie mieć możliwości zmiany ceny w kolejnych okresach. Dlatego, ustalając cenę, wówczas gdy ma taką możliwość, bierze pod uwagę średnią oczekiwaną cenę i oczekiwany popyt. Przedsiębiorstwa uwzględniają więc swoje oczekiwania w decyzjach cenowych. Ogólny poziom cen determinowany jest przez dzisiejsze oczekiwania dotyczące przyszłego poziomu cen. G.A. Calvo, Staggered Prices in Utility-Maximizing Frameworks, "Journal of Monetary Economics", Vol. 12, No. 3, 1983, s. 385-390. 
oszczędzania czy negocjacje płacowe ${ }^{3}$. Ich zakotwiczenie wspomaga bank centralny w osiąganiu celu inflacyjnego, ograniczając zmienność produkcji i zatrudnienia ${ }^{4}$. Oczekiwania inflacyjne są także przedmiotem innych badań empirycznych, które obejmują trzy obszary: sposób formułowania (racjonalność oczekiwań ze względu na jej wpływ na koszty dezinflacji), wrażliwość na zmiany bieżącej inflacji i możliwość wpływu na bieżącą dynamikę cen w gospodarce ${ }^{5}$. Osobny wątek badawczy stanowi sposób pomiaru oczekiwań inflacyjnych, które nie są zmienną bezpośrednio obserwowalną. Można szacować je za pomocą modeli, wykorzystywać dane z rynków finansowych lub opierać się na sondażach, przy czym kilka czynników przemawia za tym ostatnim rozwiązaniem: oczekiwania pozyskane $\mathrm{z}$ sondaży są lepszymi predyktorami inflacji, nie wymagają założeń apriorycznych, co ma miejsce w wypadku modeli, i nie są zanieczyszczone w sposób charakterystyczny dla danych z rynku finansowego (premia za ryzyko, koszty transakcyjne i ich wpływ na ceny aktywów) ${ }^{6}$.

Tabela 1. Mechanizm transmisji monetarnej w modelach NSN

\begin{tabular}{|c|c|c|}
\hline Równanie & Postać & Interpretacja \\
\hline Krzywa IS & $\begin{array}{l}y_{t}=-1 / \sigma\left(r_{t}-E_{t}\left\{\pi_{\mathrm{t}+1}\right\}-r_{n}\right)+E_{t}\left\{y_{t+1}\right\} \\
y_{t}-\text { luka popytowa w okresie } t, \\
\pi_{\mathrm{t}+1}-\text { inflacja w okresie } t+1, \\
r_{t}-\text { nominalna stopa procentowa w okresie } t \text {, } \\
E_{t}-\text { wartość oczekiwana w okresie } t, \\
r_{n}-\text { naturalna stopa procentowa, } \\
\sigma-\text { parametr. }\end{array}$ & $\begin{array}{l}\text { Zależność produkcji (wyrażonej w terminach luki } \\
\text { popytowej) od stopy procentowej. Równanie } \\
\text { wyprowadzone z optymalizacji dokonywanej przez } \\
\text { pojedyncze, reprezentatywne gospodarstwo domowe } \\
\text { maksymalizujące użyteczność i dokonujące wyborów } \\
\text { między czasem wolnym a pracą, wydające dochód } \\
\text { na konsumpcję i inwestycje. }\end{array}$ \\
\hline $\begin{array}{l}\text { Równanie } \\
\text { inflacji }\end{array}$ & $\begin{array}{l}\pi_{\mathrm{t}}=\alpha \mathrm{E}_{\mathrm{t}}\left\{\pi_{\mathrm{t}+1}\right\}+\beta y_{t+1} \\
\alpha, \beta-\text { parametry, } \\
\text { pozostałe oznaczenia jak wyżej. }\end{array}$ & $\begin{array}{l}\text { Inflacja zależy od oczekiwań inflacyjnych oraz luki } \\
\text { popytowej (krzywa IS). Równanie wyprowadzone } \\
\text { na podstawie koncepcji niejednoczesnego } \\
\text { dostosowywania się cen (model Calvo). }\end{array}$ \\
\hline $\begin{array}{l}\text { Reguła } \\
\text { Taylora }\end{array}$ & $\begin{array}{l}r_{t}=r_{n}+E_{t}\left\{\pi_{\mathrm{t}+1}\right\}+\gamma \mathrm{y}_{\mathrm{t}}+\lambda\left[E_{t}\left\{\pi_{\mathrm{t}+1}\right\}-\pi^{\star}\right] \\
\pi^{\star}-\text { cel inflacyjny, } \\
\gamma, \lambda \text { - parametry, } \\
\text { pozostałe oznaczenia jak wyżej. }\end{array}$ & $\begin{array}{l}\text { Funkcja reakcji banku centralnego. Nominalna stopa } \\
\text { procentowa zależy od luki popytowej i luki inflacyjnej. }\end{array}$ \\
\hline
\end{tabular}

Źródło: Opracowanie własne na podstawie J. Galí, Monetary Policy, Inflation, and the Business Cycle, An Introduction to the New Keynesian Framework, Princeton University Press, Princeton 2008, s. 41-52; R. Kokoszczyński, Współczesna polityka pieniężna w Polsce, Polskie Wydawnictwo Ekonomiczne, Warszawa 2004, s. 44-51.

3 T. Łyziak, Oczekiwania inflacyjne, w: Polityka pieniężna, red. A. Sławiński, Difin, Warszawa 2011, s. 114.

4 S. Eusepi, B. Preston, Central Bank Communication and Expectations Stabilization, NBER Working Paper Series No. 13259, Cambridge 2007, s. 36-37.

5 T. Łyziak, Inflation expectations in Poland, 2001-2013. Measurement and economic testing, National Bank of Poland Working Paper No. 178, Warsaw 2014, s. 5.

6 A. Ang, G. Bekaert, M. Wei, Do macro variables, asset markets or surveys forecasts inflation better? "Journal of Monetary Economics" 2007, Vol. 54, No. 4, s. 1163-1212. 
Zarysowane powyżej wątki sygnalizują jedynie wagę oczekiwań inflacyjnych oraz zakres badań, jakie współcześni ekonomiści prowadzą na ich temat. Jest to wymuszone przez objętość niniejszego opracowania.

\section{Wykorzystanie prognoz inflacji przez banki centralne}

Temat wykorzystania prognoz inflacji przez banki centralne może być potraktowany jedynie równie pobieżnie. Prognozy inflacji są immanentną cechą w pełni wykształconej strategii celu inflacyjnego. Wykorzystywane są ze względów praktycznych - długie opóźnienia polityki pieniężnej oznaczają potrzebę poszukiwania zmiennych umożliwiających wyprzedzające reakcje jako wsparcie procesu decyzyjnego banków centralnych oraz właśnie jako narzędzie kształtujące oczekiwania inflacyjne podmiotów gospodarczych. Funkcje prognoz inflacyjnych i ich potencjalny wpływ na oczekiwania inflacyjne przedstawiono na rysunku 1.

Już wówczas, gdy prognoza nie jest publikowana, może pełnić rolę swoistego celu pośredniego. Bank centralny wdraża wówczas szczególny proces decyzyjny - celowanie w prognozę (inflation forecast targeting). Najpierw sporządza prognozę inflacji, luki popytowej i stóp procentowych przy założeniu prowadzenia polityki według różnych wariantów, następnie wybiera preferowany scenariusz w zależności od funkcji strat, jakie minimalizuje ${ }^{7}$. Jeśli bank centralny realizuje cel inflacyjny, to w okresie $t$ powinien ustalić taką sekwencję bieżącej i przyszłych stóp procentowych, aby zminimalizować oczekiwaną zdyskontowaną na moment bieżący sumę kwadratów przyszłych odchyleń inflacji od celu. Zamiast minimalizacji oczekiwanej sumy kwadratów odchyleń przyszłej inflacji od celu, bank centralny może minimalizować odchylenia sporządzonej w momencie $t$ prognozy przyszłej inflacji od celu. Minimalizacja odchyleń ma mieć miejsce w horyzoncie transmisji monetarnej. Taką procedurę optymalizacyjną bank centralny powtarzać powinien w kolejnych cyklach decyzyjnych. Realizacja głównego celu badań - określenia współzależności między prognozami i oczekiwaniami - nie ma bezpośredniego związku z wdrażaniem celowania w prognozę. Jednak konsekwencja banku centralnego w realizacji tej procedury może mieć znaczenie dla interpretacji wyników.

\footnotetext{
7 L.E.O. Svensson et al., Implementing Optimal Policy through Inflation - Forecast Targeting, CEPR Discussion Paper No. 4229, London 2002, s. 30.

8 L.E.O. Svensson, Inflation Forecast Targeting: Implementing and Monitoring Inflation Targets, NBER Working Paper No. 5797, Cambridge 1996, s. 6-7.
} 
Rysunek 1. Wpływ prognoz inflacji na oczekiwania podmiotów gospodarczych

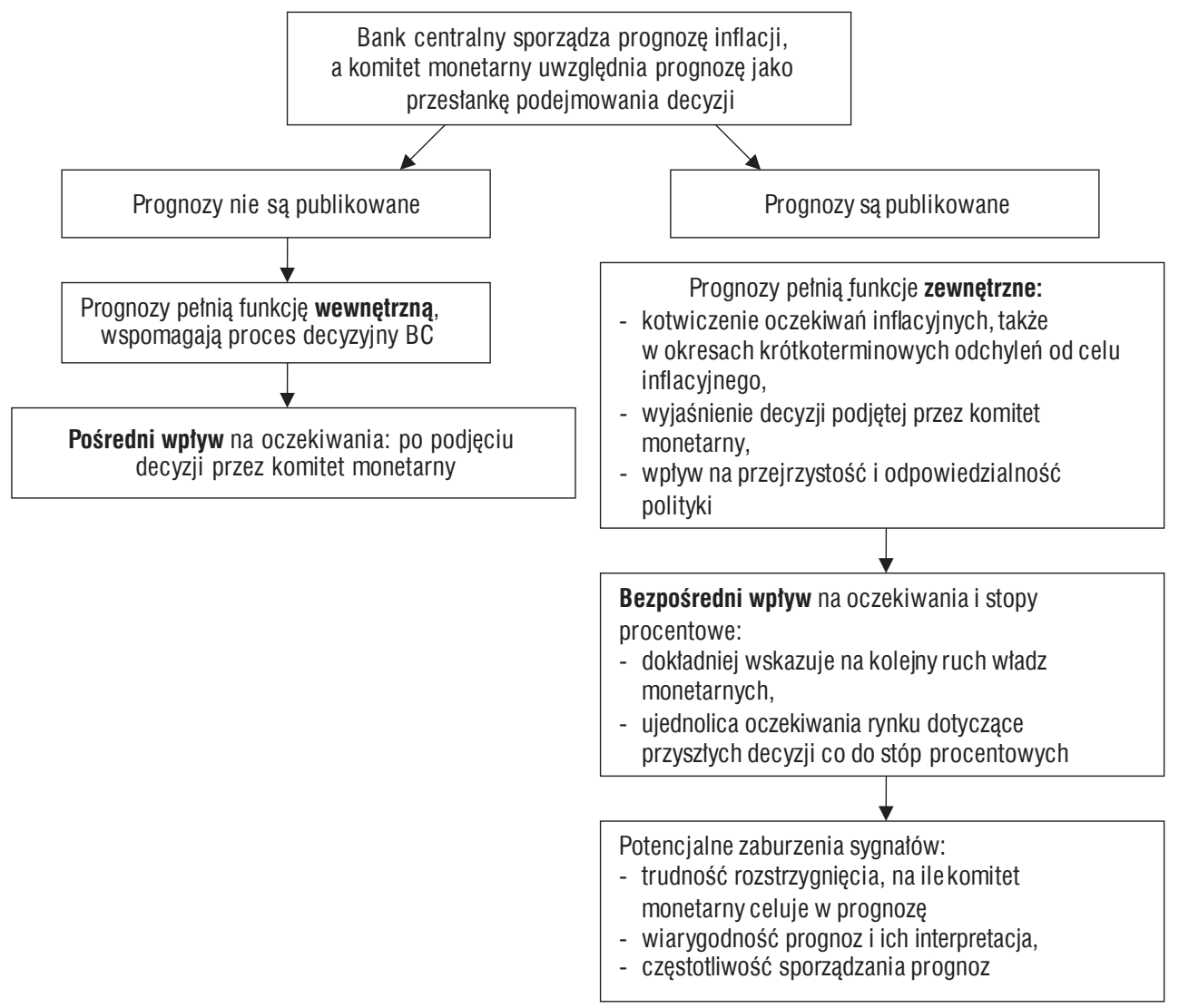

Źródło: Opracowanie własne.

Publikacja prognoz, będąca standardem w nowoczesnych bankach centralnych, umożliwia bardziej jednoznaczne oddziaływanie na oczekiwania. Na ich podstawie uczestnicy życia gospodarczego mogą kształtować oczekiwania co do przyszłego kierunku zmian, a nawet, w wypadku numerycznej publikacji ścieżki stóp, skali zmian stóp procentowych i podejmować decyzje gospodarcze. Taka jest intencja banku centralnego dążącego do kotwiczenia oczekiwań. Rynek finansowy nie jest zaskakiwany nieoczekiwanymi zmianami stóp procentowych, co prowadziłoby do ich wyższej zmienności ${ }^{9}$. Publikacja wyników prognoz prowadzi też do tego, że oczekiwania

9 M. Szyszko, Wplyw publikacji prognoz inflacji na zmienność stóp procentowych rynku międzybankowego, w: Rynek kapitałów pieniężnych. Wybrane zagadnienia, red. E. Gruszczyńska-Brożbar, „Zeszyty Naukowe” 2010, nr 164, Wydawnictwo Uniwersytetu Ekonomicznego w Poznaniu, s. 28-29. 
rynku są bardziej homogeniczne. Ma to wpływ na mniejszą zmienność stawek rynku międzybankowego, stóp terminowych i wyceny aktywów ${ }^{10}$. Podobnie pozytywny wpływ na homogeniczność stóp procentowych ma publikowanie w Raportach o inflacji oceny stanu gospodarki, co daje uczestnikom rynku szansę spojrzenia na gospodarkę oczami banku centralnego.

Sformułowanie "publikacja prognoz” odnosi się w zasadzie do wszystkich sposobów publikacji wyników prognoz inflacji. Tymczasem publikacja ta może mieć rozmaite formy, uzależnione od tego, w jaki sposób bank centralny prognozuje inflację oraz od tego, co faktycznie chce pokazać uczestnikom rynku. Podstawową - i najczęściej wyjściową - wersją prognozy jest tzw. projekcja (prognoza warunkowa) powstała przy szczególnym założeniu o braku zmian stopy banku centralnego (niekiedy także kursu walutowego) w horyzoncie prognoz. W takich prognozach zakłada się, że stopa banku centralnego jest stała (podobnie stopa rynkowa, choć ta może zmieniać się zgodnie z oczekiwaniami rynku). Coraz częściej banki centralne sporządzają i publikują prognozę bezwarunkową, endogenizując ścieżkę stóp. Niesie to ze sobą konieczność budowy funkcji reakcji komitetu monetarnego, co rodzi trudności koncepcyjne i metodologiczne ${ }^{11}$, a po opublikowaniu ścieżki - interpretacyjne dla uczestników rynku.

Dyskusja na temat zalet i wad prognozy bezwarunkowej, a w szczególności publikacji ścieżki, jest jedną z żywotnych debat w polityce pieniężnej. Niektóre analizy teoretyczne wskazują, że jeśli publiczność nie zna w pełni funkcji celu lub funkcji reakcji banku centralnego, to opublikowanie ścieżki stóp procentowych pozwala poprawić wyniki gospodarki. W takich warunkach uczestnicy rynku na podstawie przeszłych decyzji komitetu monetarnego szacują parametry funkcji celu i funkcji reakcji. Podanie do wiadomości ścieżki stóp sprawia, że oczekiwania uczestników rynku są bardziej zbieżne z oczekiwaniami banku centralnego, co ogranicza wahania produkcji i inflacji ${ }^{12}$. Inne badania potwierdzają co prawda, że przy założeniu asymetrii informacji między bankiem centralnym a społeczeństwem, odkrywanie kolejnych informacji pozwala obniżyć jego stratę (celem banku jest minimalizacja

${ }_{10}$ M. Ehrmann, D. Sondermann, The Reception of Public Signals on the Financial Markets. What if Central Bank Communication Become Stale?, "ECB Working Paper Series" No. 1077, Frankfurt am Main 2009, s. 16-21. Badania przeprowadzono na podstawie informacji ujawnianych w Raportach o inflacji przez Bank Anglii.

${ }^{11}$ Najczęściej jest nią reguła Taylora w wersji forward-looking. Jest ona krytykowana w literaturze, zob. Taylor Interest Rate and Monetary Condition Index, Deutsche Bundesbank Montly Report, April 1999, Deutsche Bundesbank, Frankfurt am Main 1999. Nie wypracowano dotychczas innych rozwiązań zadowalających z punktu widzenia teoretycznego i aplikacyjnego, a reguła Taylora może być wyprowadzona jako optymalna reguła polityki dla modeli ujmujących mikropodstawy (DSGE).

${ }^{12}$ G. Rudebusch, J. Williams, Revealing the Secrets of the Temple: the Value of Publishing Central Bank's Interest Rate Projections, "Federal Reserve Bank of San Francisco Working Paper" 2006, No. 31, s. 6. 
określonej funkcji strat), ale relatywnie więcej zyskuje on na ujawnieniu prognozy w ogóle (punktem wyjścia było jej nieujawnianie) niż na ujawnieniu ścieżki stóp ${ }^{13}$.

Ten ostatni argument sprawił, że badania nad wpływem prognoz inflacji na oczekiwania inflacyjne zostały oparte na wyniku prognozy także dla banków, które publikują ścieżkę stóp. Zasadniczo, ścieżka stóp procentowych spójna z prognozą powinna doprowadzić prognozę inflacji w horyzoncie transmisji monetarnej do poziomu celu inflacyjnego. Uczestnicy rynku oceniają najprostszą informację - czy w ciągu roku (w horyzoncie transmisji monetarnej), bank centralny doprowadzi inflację do poziomu celu inflacyjnego. Takie uproszczenie zasadne wydaje się szczególnie w wypadku badania oczekiwań inflacyjnych konsumentów, co ma związek z ich relatywnie niską wiedzą ekonomiczną. Są oni wtórnymi odbiorcami prognoz inflacji.

Podsumowując rozważania na temat prognoz inflacji i ich związków z oczekiwaniami inflacyjnymi należy podkreślić, że podstawową funkcją prognoz ma być wpływ na oczekiwania inflacyjne. $Z$ drugiej strony, to same oczekiwania mogą stanowić estymatory przyszłej inflacji.

\section{Metodologia badań}

Badania przeprowadzono na próbie dwóch krajów. Podstawowe dane na temat próby przedstawiono w tabeli 2 . Zakres czasowy badania zdeterminowany był ostatnią istotną zmianą w systemie prognozowania w bankach centralnych. Dla obu banków oznaczało to przejście do endogenizowania stóp procentowych.

Oczekiwania inflacyjne zostały skwantyfikowane skorygowaną metodą probabilistyczną Carlsona i Parkina, w której zakłada się, że oczekiwana stopa inflacji ma rozkład normalny o nieznanych parametrach ${ }^{14}$. Ankietowani odpowiadają na pytania sondażowe, składając deklaracje dotyczące przebiegu procesów inflacyjnych i odnoszące się do bieżących procesów inflacyjnych. Badania przeprowadzane są z częstotliwością miesięczną ${ }^{15}$.

${ }_{13}$ M. Brzoza-Brzezina, A. Kot, The Relativity Theory Revised: Is Publishing Interest Rates Forecast Really so Valuable?, "National Bank of Poland Working Papers" 2008, No. 52, s. 10-13.

14 T. Łyziak, Consumer Inflation Expectations in Poland, "ECB Working Paper Series", Working Paper 2000, No. 287, s. 11-13.

15 Pytanie sondażowe brzmi: W porównaniu z ostatnim rokiem, jak Pani/Pana zdaniem kształtować się będą ceny w kolejnych 12 miesiącach? Respondenci wybierają wśród odpowiedzi: a) będą rosły szybciej, b) będą rosły w tym samym tempie, c) będą rosły wolniej, d) pozostaną na tym samym poziomie, e) spadną, f) nie wiem. 
Tabela 2. Próba i sposób kodowania danych

\begin{tabular}{|c|c|c|}
\hline Cecha & CNB & SR \\
\hline Liczba prognoz & 50 & 46 \\
\hline Liczba miesięcy (oczekiwania) & 151 & 96 \\
\hline Okres & Lipiec 2002-2014 & 2007-2014 \\
\hline Dane 0 oczekiwaniach & \multicolumn{2}{|c|}{$\begin{array}{l}\text { Skwantyfikowane oczekiwania inflacyjne, dane źródłowe } \\
\text { z Business and Consumers Surveys }\end{array}$} \\
\hline Wyniki prognoz & \multicolumn{2}{|c|}{$\begin{array}{l}\text { Raporty o inflacji i Raporty o polityce pieniężnej, dane zakodowane w sposób spójny } \\
\text { z określeniem celu inflacyjnego: } \\
\text { - } 2 \text { ścieżka centralna poniżej dolnej granicy wahań celu, } \\
\text { - } 1 \text { ścieżka centralna poniżej celu, ale w granicach wahań, } \\
0 \text { ścieżka centralna na poziomie celu, } \\
1 \text { ścieżka centralna powyżej celu inflacyjnego, ale w granicach wahań, } \\
2 \text { ścieżka centralna powyżej górnej granicy celu inflacyjnego. } \\
\text { Relacja ścieżki centralnej sprawdzana dla początku horyzontu transmisji monetarnej } \\
\text { (rok po powstaniu prognozy). Jest to spójne z pytaniami sondażowymi o oczekiwane } \\
\text { zmiany poziomu cen za } 12 \text { miesięcy. }\end{array}$} \\
\hline
\end{tabular}

Uwaga: Zbliżonej liczbie prognoz inflacji towarzyszy znacznie większa liczba miesięcy w Czechach ze względu na to, że prognozy sporządzane są tam z częstotliwością kwartalną, w Szwecji natomiast uwzględniono wyniki trzech prognoz i ich trzech aktualizacji.

Źródło: Opracowanie własne.

Wyniki prognoz zostały zakodowane $\mathrm{z}$ kilku powodów. Po pierwsze, badanie obejmuje oczekiwania inflacyjne konsumentów. Ta grupa niespecjalistów nie rozumie skomplikowanego przekazu zakodowanego w komunikatach banku centralnego. Porównanie ścieżki centralnej do celu inflacyjnego jest czytelnym uproszczeniem tego przekazu. Po drugie, banki centralne z jednej strony deklarują wzrastającą przejrzystość, z drugiej, nie zawsze chętnie ujawniają dodatkowe informacje (poza tymi $\mathrm{z}$ raportów), np. dla potrzeb badawczych. Zabieg kodowania został przeprowadzony dla ujednolicenia wyliczeń ${ }^{16}$.

Ze względu na inną częstotliwość sporządzania prognoz (w Czechach - kwartalną, w Szwecji od 2007 roku - sześć prognoz, w tym trzy prognozy i trzy uaktualnienia) oraz oczekiwań (sondaże miesięczne), w tych miesiącach, w których nie było prognozy, do badań przyjmowano jej ostatni poziom. Oznacza to założenie, że jedna prognoza miała wpływ na oczekiwania w miesiącu jej sporządzenia i w kolejnych miesiącach - do czasu ukazania się nowej prognozy.

16 Zaprezentowane w artykule badanie jest częścią badań przeprowadzonych na większej grupie krajów. Początkowo banki centrale ujawniały prognozę opisowo. Część z nich odmawia prośbom o udostępnienie danych. Dla tych państw, w których było to możliwe, wykonano obliczenia dla wyników prognoz liczbowo określonych i potwierdziły one wyniki podstawowe. 
W badaniach uwzględniono również opóźnienia: prognoza z okresu $t$ mogła mieć wpływ nie tylko na oczekiwania z tego samego miesiąca, w którym została opublikowana $^{17}$, ale również w kolejnych miesiącach.

Do badania współzależności wykorzystano, ze względu na zakodowanie danych na temat prognoz, podstawowe testy korelacji nieparametrycznych.

\section{Wyniki badań empirycznych}

Wyniki zawarte w tabeli 3 potwierdzają istnienie współzależności między prognozami inflacji a oczekiwaniami inflacyjnymi. Zależności te są statystycznie istotne (dla poziomu istotności 0,05). O ile dla Szwecji zależność między zmiennymi jest znacząca, o tyle w wypadku Czech - słaba. Różnice te można wyjaśnić dwoma czynnikami. Pierwszym jest znacznie dłuższa historia monetarna Szwecji. Sveriges Riksbank po raz pierwszy sformułował cel inflacyjny w $1993 \mathrm{r}$. - jako jeden z pierwszych banków rozpoczął wdrażanie strategii bezpośredniego celu inflacyjnego. Historia NBC w zakresie wdrażania strategii celu inflacyjnego jest krótsza - rozpoczęła się w 1998 r. Drugi powód związany jest z konsekwencją obu banków we wdrażaniu celowania w prognozę. Oba podmioty deklarują kierowanie się prognozą przy podejmowaniu decyzji i zasadniczo ją uwzględniają. Ze względu na specyficzne uwarunkowania polityki monetarnej NBC od 2013 r. nie może w zasadzie zmieniać stóp procentowych zgodnie $\mathrm{z}$ wynikiem prognoz - obniżywszy podstawową stopę procentową do poziomu 0,05\% w listopadzie 2012 r., NBC w zasadzie funkcjonuje $\mathrm{w}$ warunkach zerowych nominalnych stóp procentowych. W tym okresie zapowiadał co prawda poluzowanie warunków monetarnych poprzez interwencję na rynku walutowym (a nawet dokonywał takich interwencji), jednak działanie to, szczególnie dla konsumentów, jest mniej czytelne niż wykorzystanie standardowego narzędzia, jakim jest obniżka stóp procentowych. Takie wyjaśnienie potwierdzać może fakt, że w wypadku skrócenia próby badawczej dla Czech współczynniki korelacji wzrastają.

Wysoka siła współzależności odnotowana dla Szwecji jest zaskakująca wobec faktu, że badaniu podlegały oczekiwania inflacyjne najmniej wykształconej ekonomicznie grupy podmiotów - konsumentów ${ }^{18}$.

\footnotetext{
17 Niekiedy - ze względu na harmonogram publikacji - prognoza nie mogła mieć wpływu na oczekiwania $\mathrm{z}$ analogicznego miesiąca, bo została opublikowana po przeprowadzeniu sondażu.

18 Oczekiwania badane są wśród gospodarstw domowych, przedsiębiorstw specjalistów rynku finansowego. Gospodarstwa domowe są najmniej wykształcone w tej grupie.
} 
Tabela 3. Współzależności między prognozami a oczekiwaniami

\begin{tabular}{|c|c|c|c|c|c|}
\hline Kraj & Statystyka/opóźnienie & $\mathrm{t}$ & $t+1$ & $t+2$ & $t+3$ \\
\hline \multirow{3}{*}{ 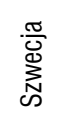 } & Spearman & 0,703830 & 0,730024 & 0,751113 & 0,754107 \\
\hline & Gamma & 0,736215 & 0,765329 & 0,781538 & 0,780297 \\
\hline & Kendall & 0,564824 & 0,588714 & 0,602763 & 0,603379 \\
\hline \multirow{3}{*}{$\begin{array}{l}\text { त्रे } \\
\text { N } \\
\text { U. }\end{array}$} & Spearman & 0,300223 & 0,315742 & 0,323945 & 0,344746 \\
\hline & Gamma & 0,278290 & 0,294854 & 0,302782 & 0,319144 \\
\hline & Kendall & 0,238926 & 0,253425 & 0,260584 & 0,274611 \\
\hline
\end{tabular}

Źródło: Opracowanie własne.

W obu wypadkach (i niezależnie od stosowanej statystyki), wraz z wydłużeniem opóźnienia rośnie siła współzależności. Informacja o wyniku prognozy inflacji musi dotrzeć do konsumentów - niespecjalistów. Wątpliwości nie budzi również fakt, że współzależności są dodatnie. Jeśli prognoza wskazuje na przekroczenie celu inflacyjnego, konsumenci mogą spodziewać się inflacji wyższej niż ogłoszona (cel inflacyjny). Sytuacja taka jest szczególnie uwypuklona w tych bankach centralnych, które endogenizują stopę procentową (jak Sveriges Riksbank i NBC). Spójna z prognozą stopa procentowa powinna doprowadzić inflację w horyzoncie transmisji monetarnej do poziomu docelowego. Jeśli tak nie jest, to odbiorcy prognoz dostają sygnał, że bank centralny nie jest w stanie sprowadzić inflacji na poziom celu.

\section{Podsumowanie}

Zaprezentowane $\mathrm{w}$ tekście badania potwierdzają istnienie statystycznie istotnej współzależności między wynikami prognoz inflacji dwóch banków centralnych a oczekiwaniami inflacyjnymi konsumentów w Czechach i w Szwecji. Postawiona we wstępie hipoteza badawcza została zweryfikowana pozytywnie. Różna jest skala tych współzależności - od relatywnie słabej dla Czech do ok. 70\% dla Szwecji. Różnice te otwierają pole dla dalszych badań i interpretacji. Przedstawione w niniejszym artykule badania są częścią szerszego projektu badawczego. Wyjaśnienia różnic w sile współzależności poszukiwać należy m.in. w przejrzystości polityki pieniężnej (w szczególności - systemu prognozowania inflacji), wiarygodności polityki monetarnej, konsekwencji banku centralnego we wdrażaniu celowania w prognozę.

Niezależnie od koniecznej ostrożności w formułowaniu wniosków - badaniu poddano współzależności, a nie związek przyczynowo-skutkowy, wnioski z badań są cenne dla banków centralnych. Po pierwsze, wskazują na faktyczne wypełnienie 
funkcji czynnika kształtującego oczekiwania przez prognozy inflacji. Sygnalizują tym samym, czy system prognozowania i sposób komunikowania wynikający z prognoz wymagają modyfikacji. Po drugie, umożliwiają analizę porównawczą skuteczności - w sensie siły związku - wdrażanych rozwiązań.

Problematyka kształtowania oczekiwań inflacyjnych pozostanie w kolejnych latach w centrum zainteresowania banków centralnych. Kryzys zapoczątkowany w ubiegłym dziesięcioleciu na rynku amerykańskim przyniósł co prawda wzmożoną dyskusję na temat ram polityki pieniężnej i optymalnego sposobu jej prowadzenia, nie doprowadziła ona jednak do znaczącej zmiany postrzegania współczesnego mechanizmu transmisji monetarnej. Uwypuklono znaczenie zmiennych monetarnych i kanału aktywów w mechanizmie transmisji monetarnej, bank centralny został także obarczony explicite celem w postaci wsparcia stabilności finansowej. Nie zanegowano jednak roli oczekiwań inflacyjnych w polityce monetarnej. Dyskusja nad optymalnym wykorzystaniem narzędzi, które mogą wspierać kształtowanie oczekiwań podmiotów gospodarczych jest dalej otwarta. Przedstawione wyniki badań są jednym $\mathrm{z}$ jej nurtów.

\section{Bibliografia}

Ang A., Bekaert G., Wei M., Do macro variables, asset markets or surveys forecasts inflation better?, "Journal of Monetary Economics" 2007, Vol. 54, No. 4.

Brzoza-Brzezina M., Kot A., The Relativity Theory Revised: Is Publishing Interest Rates Forecast Really so Valuable?, "National Bank of Poland Working Papers" 2008, No. 52.

Calvo G.A., Staggered Prices in Utility-Maximizing Frameworks, "Journal of Monetary Economics" 1983, Vol. 12, No. 3.

Ehrmann M., Sondermann D., The Reception of Public Signals on the Financial Markets. What if Central Bank Communication Become Stale?, "ECB Working Paper Series" 2009, No. 1077, Frankfurt am Main.

Eusepi S., Preston B., Central Bank Communication and Expectations Stabilization, "NBER Working Paper" 2007, No. 13259, Cambridge.

Galí J., Monetary Policy, Inflation, and the Business Cycle, An Introduction to the New Keynesian Framework, Princeton University Press, Princeton 2008.

Kokoszczyński R., Współczesna polityka pieniężna w Polsce, PWE, Warszawa 2004.

Łyziak T., Consumer Inflation Expectations in Poland, "ECB Working Paper Series" 2000, No. 287. 
Łyziak T., Inflation expectations in Poland, 2001-2013. Measurement and economic testing, "National Bank of Poland Working Paper" 2014, No. 178.

Łyziak T., Oczekiwania inflacyjne, w: Polityka pieniężna, red. A. Sławiński, Difin, Warszawa 2011.

Rudebusch G., Williams J., Revealing the Secrets of the Temple: the Value of Publishing Central Bank's Interest Rate Projections, "Federal Reserve Bank of San Francisco Working Paper" 2006, No. 31.

Svensson L.E.O., Inflation Forecast Targeting: Implementing and Monitoring Inflation Targets, "NBER Working Paper" 1996, No. 5797, Cambridge.

Svensson L.E.O. etal., Implementing Optimal Policy through Inflation - Forecast Targeting, “CEPR Discussion Paper" 2002, No. 4229, London.

Szyszko M., Wplyw publikacji prognoz inflacji na zmienność stóp procentowych rynku międzybankowego, w: Rynek kapitałów pieniężnych. Wybrane zagadnienia, red. E. Gruszczyńska-Brożbar, „Zeszyty Naukowe” 2010, nr 164, Wydawnictwo Uniwersytetu Ekonomicznego w Poznaniu.

Taylor Interest Rate and Monetary Condition Index, "Deutche Bundesbank Montly Report" 1999, Deutsche Bundesbank, Frankfurt am Main.

The Joint Harmonised EU Programme of Business and Consumer Surveys, User Guide, European Commission 2007.

\section{Shaping of Inflation Expectations Through Inflation Forecasts. The Results of Empirical Research}

The article focuses on aspects of modern monetary strategy: inflation expectations and inflation forecasts. Inflation forecasts' main function is shaping inflation expectations. The deeper the impact of a central bank on expectations, the easier its task of stabilization of inflation on the targeted level. The article presents the results of empirical research that verifies the hypothesis on existence of interdependences of inflation forecasts and inflation expectations. The research covers two countries: Sweden and the Czech Republic. The research methodology includes quantitative methods: quantification of expectations (Carlson-Parkin method) and non-parametric statistics of interdependences. The research confirms the existence of statistically important interdependences of inflation forecasts and expectations in both countries. Their strength is remarkable for Sweden (c.a. 0.70) and much weaker for the Czech Republic (c.a. 3.0).

Keywords: monetary policy, inflation forecasts, inflation expectations 


\section{Façonner des anticipations d'inflation grâce à des prévisions d'inflation. Les résultats de la recherche empirique}

L'article se concentre sur les aspects de la stratégie monétaire moderne: les anticipations d'inflation et les prévisions d'inflation. La fonction principale des prévisions d'inflation est de façonner les attentes d'inflation. L'article présente les résultats de la recherche empirique qui vérifie l'hypothèse de l'existence de l'interdépendance entre les prévisions et les anticipations d'inflation. La recherche couvre deux pays: la Suède et la République tchèque. La méthodologie comprend des méthodes quantitatives. La recherche confirme l'existence de l'interdépendance statistiquement significative entre les prévisions et les attentes d'inflation dans les deux pays. La force de l'interdépendance est remarquable pour la Suède (0.70) et beaucoup plus faible pour la République tchèque (3.0).

Mots-clés: la politique monétaire, les prévisions d'inflation, les anticipations d'inflation

\section{Формирование инфляционных ожиданий посредством прогноза инфляции. Результаты эмпирических исследований}

Статья посвящена аспектам современной денежно-кредитной стратегии: инфляционным ожиданиям и прогнозам по инфляции. Основной функцией прогнозов инфляции является формирование инфляционных ожиданий. Чем сильнее воздействие центрального банка на ожидания, тем легче стабилизация инфляции на целевом уровне. В статье представлены результаты эмпирического исследования, в котором проверяется гипотеза о существовании взаимозависимости инфляционных прогнозов и инфляционных ожиданий. Исследование охватывает две страны: Швецию и Чехию. Методология исследования включает в себя количественные методы: метод квантификации ожиданий (метод Карлсона-Паркина) и непараметрические статистики. Исследование подтверждает существование статистически значимых взаимосвязей между инфляционными прогнозами и ожиданиями в обеих странах. Она довольно сильна в Швеции (около 0,70) и гораздо слабее для Чешской Республики (около 3,0).

Ключевые слова: денежно-кредитная политика, прогноз инфляции, инфляционные ожидания 
